\title{
EWOLUCJA ZAGROŻENIA DŻIHADYSTYCZNEGO W EUROPIE
}

Zagrożenie terrorystyczne na początku XXI wieku stanowi jedno z najpoważniejszych wyzwań dla bezpieczeństwa państw europejskich. Jego ewolucja ściśle wiąże się z pojawieniem nowej zmiennej w postaci czynnika religijnego i wzrostu znaczenia grup radykalnych czy nawet jednostek odwołujących się do radykalnych haseł (Wojciechowski, 2013a: 134-135). Zmiany te przebiegają w ostatnich dwóch dekadach coraz szybciej ściśle łącząc się w istocie z unifikacją wyboru przez religijnych ekstremistów strategii i taktyki walki o cele polityczno-religijne (Wojciechowski, 2013b: 136-138). W okresie ostatnich trzech dekad zjawisko terroryzmu religijnego w Europie pokonało dwa etapy rozwoju, wchodząc na początku drugiej dekady w trzeci, niezwykle groźny etap. Najczęściej kojarzony jest on z aktywnością terrorystów (najczęściej muzułmanów, w tym też i konwertytów), którzy przeszli proces autoradykalizacji (zjawisko terroryzmu indywidualnego) lub też komórek operacyjnych, zwykle najwyżej kilkuosobowych, które działają niezależnie od siebie, bardzo rzadko kontaktując się ze strukturami nadrzędnymi (np. Centralnym Dowództwem Al-Kaidy). Aktywność ekstremistów obejmuje zarówno świat realny, jak też i wirtualny, prowadząc do proliferacji radykalnych postaw oraz popularyzacji wiedzy techniczno-taktycznej, która może z powodzeniem być wykorzystana w działalności operacyjnej.

W związku z powyższymi obserwacjami, warto postawić kilka pytań: czy ewolucja ruchu dżihadystycznego wpłynęła w widoczny sposób na wzrost zagrożenia bezpieczeństwa państw europejskich? Jaki charakter mają owe zagrożenia i jaki jest ich poziom?

\section{ISTOTA ZAGROŻENIA DŻIHADYSTYCZNEGO}

W okresie ostatnich trzech dekad zjawisko dżihadyzmu przeszło znaczącą ewolucję. W najogólniejszym sensie dżihadyzm powinien być utożsamiany ze sposobem myślenia prezentowanym przez najbardziej skrajne środowiska islamskich radykałów, polegającym na wybiórczym podejściu do interpretacji terminu ,dżihad” (w tym przypadku chodzi o ten $z$ aspektów, który dotyczy ofensywnego użycia przemocy). Wedle Thomasa Hegghammera termin ten pojawił się w analizach akademickich dopiero w dekadzie lat dziewięćdziesiątych XX wieku (Hegghammer, 2009: 246). Spopularyzowany został nie tylko w środowiskach naukowych i decydenckich świata zachodniego, ale także wśród islamskich radykałów. Dżihadyści uważają siebie za awangardę 
świata muzułmańskiego, która stoi na straży czystości wiary muzułmańskiej, a więc kierunku wskazanego przez Mahometa i pierwszych kalifów (Brachman, 2009: 4-5). Farhard Khosrokhavar uznaje dżihadyzm za największy ze współcześnie istniejących, utopijny, antyzachodni w swej istocie ruch społeczny, który realizację najważniejszych celów opiera na użyciu przemocy (Khosrokhavar, 2009: 1). Dżihadyści należą do grupy islamistów wyznających ortodoksyjnie rozumianą koncepcję dżihadu (świętej wojny) i odwołujących się do idei związanych z postulatami restytucji relacji społeczno-politycznych z okresu początków islamu.

Do globalnego ruchu dżihadystycznego może w istocie przyłączyć się każda sunnicka grupa radykalna, której bliskie są cele ruchu i której założyciele (przywódcy) są skłonni podporząadkować się założeniom strategiczno-taktycznym ruchu oraz złożyć przysięgę wierności. W okresie ostatnich kilkunastu lat ich łączna liczba przekroczyła pułap trzydziestu ugrupowań i ciagle rośnie (Wejkszner, 2010: 122). Jednym z najbardziej radykalnych uczestników, nowych uczestników ruchu wydaje się być np. grupa Boko Haram z Nigerii, odpowiedzialna za wiele znaczących zamachów terrorystycznych w tym kraju w okresie ostatnich trzech lat.

Choć terroryści islamscy działają lokalnie, to łączy ich globalna wizja, którą Olivier Roy określił mianem aterytorialnego globalnego dżihadu, wynikającego z kolektywnego obowiązku (fard kifaja) (Roy, 2004: 41). Frazer Egarton wskazał ponadto, iż na ponadnarodowy, ideologiczny aspekt łączący aktywność dżihadystów w Europie. Jest nim idea zbrojnej ummy walczącej o przetrwanie społeczności islamskiej (Egarton, 2011: 127). Dzięki tej idei możliwe jest połączenie wysiłków muzułmanów z całego świata, z pominięciem różnic lokalnych, wokół wspólnego przedsięwzięcia. Niektórzy autorzy mylnie sądzą, iż jest to wirtualna idea, $z$ europocentrycznego, a więc i narodowocentrycznego punktu widzenia całkiem anachroniczna (Sageman, 2004: 161). Dla muzułmanów przekłada się jednak na prostą perspektywę konfliktu społecznego: wyznawcy islamu kontra jego przeciwnicy.

Na przestrzeni trzech ostatnich dekad ewolucji uległa struktura organizacyjna ruchu dżihadystycznego. Na początku lat dziewięćdziesiątych, w ramach tzw. klasycznej Al-Kaidy wyróżnić można było strukturę hierarchiczną, która z czasem z uwagi na czynniki obiektywne (m.in. aktywność antyterrorystyczną państw zachodnich) i subiektywne (absorbowanie przez członków ruchu sprawdzonych wzorców działania) uległa spłaszczeniu, przyjmując postać struktury sieciowej z elementami hierarchicznymi (Wejkszner, 2012: 65). Proces ten ma jednak charakter immanentny, a w jego ramach widoczne są tendencje amorfizacji powyższej struktury.

W ramach ostatniego etapu ewolucji dżihadyzmu w Europie spopularyzowana została idea terroryzmu indywidualnego. Jednym z jej propagatorów był Abu Abdul Rahman Attija al-Libi ${ }^{1}$. W materiałach szkoleniowych udostępnianych na forach dżihadystycznych zachęcał do podjęcia indywidualnego dżihadu (al dżihad al fardi). Adresatami tego wezwania byli przede wszystkim muzułmanie mieszkający na Zachodzie.

1 Attija był jednym z przywódców ruchu dżihadystycznego w Libii. Ukończył on studia koraniczne w Mauretanii. W obozach szkoleniowych Al-Kaidy zdobył wiedzę z zakresu produkcji i użycia materiałów wybuchowych. Nawiązał też bliskie kontakty z przywódcami Centralnego Dowództwa Al-Kaidy - m.in. z Ajmanem al-Zawahirim. 
Zawierało ono m.in. szczegółowe wskazania taktyczne, do których muzułmanie powinni się zastosować (al-Shishani, 2011: 8). Nie był on jednak prekursorem promowania tego typu taktyki w ramach ruchu dżihadysytycznego. Niecałą dekadę wcześniej podobne idee głosił Abu Musab al Suri - jeden z głównych ideologów Al-Kaidy. W swoim monumentalnym 1500 stronicowym dziele twierdził, iż taktyka walki indywidualnej należy, w dobie globalizacji i wszechobecnej inwigilacji do jednej z najefektywniejszych.

\section{TRZY ETAPY EWOLUCJI DŻIHADYZMU W EUROPIE}

Członkowie ruchu sukcesywnie w latach dziewięćdziesiątych rozbudowywali swe wpływy na kontynencie europejskim (Pargeter, 2008: 64-97). Na przestrzeni kolejnych lat, a zwłaszcza po atakach z 11 września 2001 r. zmienił się sposób funkcjonowania ruchu. Europa stała się, zdaniem Abdela Bariego Atwana, głównym celem aktywności ruchu i drugim, po Bliskim Wschodzie, polem bitwy (Atwan, 2008: 250). Kolejne konflikty toczone w Afganistanie i Iraku doprowadziły do pojawienia się rzeszy muzułmańskich uchodźców w Europie. Wiele państw zachodnioeuropejskich zaoferowało im azyl. Także wielu europejskich muzułmanów, zainspirowanych ideologia globalnego salafickiego dżihadu, a zwłaszcza młodzież, szukało kontaktu z przedstawicielami radykalnych grup. Łatwość uzyskania azylu na Zachodzie, ale też względna łatwość podróży Europejczyków na Bliski Wschód do stref konfliktów pozytywnie wpłynęły na rozwój wpływów Frontu na tym kontynencie. A. B. Atwan nazywa tego typu fenomen „turystyką dżihadystów”, zauważając przy okazji nowe zjawisko w postaci podejmowania ataków skierowanych przeciwko państwom swego pochodzenia (ibidem: 251).

Nie wydaje się już możliwe funkcjonowanie ruchu w Europie na zasadach wypracowanych w latach dziewięćdziesiątych XX wieku. Poszczególnych komórek nie tworzą już przysłani z baz ugrupowania mudżahedini. Jest to raczej ruch oddolny, wynikający ze wzrostu popularności radykalnej ideologii salafickiego dżihadu. Terrorystyczne sieci ruchu kształtują się przede wszystkim w sposób autonomiczny, przejmując i wykorzystując wypracowane modelowe rozwiązania. Innym sposobem ich powstawania była ideologiczna infiltracja działających już efektywnie sieci radykalnych ugrupowań muzułmańskich. Na początku XXI wieku do najlepiej rozwiniętych należały sieci - algierskiego Islamskiego Frontu Ocalenia, Islamskiej Grupy Zbrojnej oraz Salafickiej Grupy Modlitwy i Walki.

Zinfiltrowanie sieci komórek algierskich organizacji terrorystycznych powiodło się przedstawicielom globalnego ruchu salafickiego dżihadu zdaniem Rohana Gunaratny jedynie częściowo. Większy sukces odniesiono w stosunku do sieci Takfir Wal Hidżra. Jej korzenie rozpościerają się na państwa Maghrebu. Jednym z jej szefów był swego czasu Ayman al-Zawahiri. Dwoma kolejnymi sukcesami okazało się zinfiltrowanie sieci Islamskiej Grupy Zbrojnej oraz Salafickiej Grupy Modlitwy $i$ Walki. Duża część europejskich kadr sieci ruchu, z uwagi na powyższe działania jest pochodzenia algierskiego, ale także egipskiego, tunezyjskiego, libijskiego i marokańskiego. Są to zazwyczaj potomkowie, w pierwszym lub drugim pokoleniu, imigrantów, którzy przybyli do Eu- 
ropy za chlebem (Renard, 2008: 3-6) ${ }^{2}$. Niewielką część członków sieci stanowią konwertyci i inna ludność napływowa wyznająca islam (Gunaratna, 2003: 153-154). Według R. Gunaratny, który opiera swe przybliżenia na danych agencji wywiadowczych, przybliżona łączna liczba osób, wchodzących w skład sieci Frontu w Europie ok. 2002 r. oscylowała wokół liczby 500 (ibidem: 154). Do 2001 r. w wyniku aresztowań wolność straciło ok. 150 bojowników.

Sieci ruchu nałożyły się w ograniczonym jednakże wymiarze na sieci organizacji przestępczych w Europie, przede wszystkim z uwagi na konieczność akumulacji przez organizację środków finansowych na swoją działalność oraz zapewnienia operacyjnych możliwości funkcjonowania poszczególnym członkom grupy, np. zdobycia fałszywych dokumentów tożsamości, przerzutu nowych członków sieci do Europy itp. (ibidem).

Kolejnym ważnym aspektem ewolucji działalności ruchu w Europie, zgodnie z oświadczeniem udostępnionym przez Osamę bin Ladena 23 kwietnia 2006 r., stało się zdecydowane reagowanie na przejawy dyskryminowania muzułmanów na płaszczyźnie kulturalnej lub moralnej. Przykładem tego typu aktywności było m.in. zabójstwo oskarżanego o bluźnierstwo reżysera Theo Van Gogha.

Niezmiernie ważne wydaje się podkreślenie, że ruch nigdy nie tworzył, także w Europie, sieci ograniczonych terytorialnie. Skład personalny poszczególnych komórek nie ograniczał się nigdy do obywateli konkretnego państwa. Zasięg ich aktywności nigdy nie był ograniczony granicami państwowymi. Tym niemniej z uwagi na rekrutację odbywającą się w sposób immanentny w tych krajach europejskich, w których jest duża liczba muzułmańskich imigrantów oraz konieczność realizowania zadań operacyjnych i logistycznych działalność poszczególnych komórek można opisać posługując się kluczem geograficznym (Vidino, 2007: 8-9).

Mając na uwadze powyższe fakty, warto dokonać periodyzacji rozwoju globalnego ruchu salafickiego dżihadu na kontynencie europejskim (Nesser, 2008: 237). Rozwój ten przebiegał co najmniej w trzech etapach. Pierwszy z nich obejmował okres od początku dekady lat 90. XX w. do 1998 r. W Europie aktywne były wówczas przede wszystkim sieci terrorystyczne organizacji, które później zinfiltrowane zostały przez bojowników ruchu. Granicznym wydarzeniem było w tym wypadku tworzenie Światowego Frontu Islamskiego. To wydarzenie miało zaś wpływ na ewolucję strategii i taktyki działania, co w szczególności przejawiało się w przejściu od fazy dżihadu lokalnego do globalnego. Drugi z okresów obejmował swym zasięgiem okres od 1998 do 2005 r. Kraje europejskie stały się wówczas areną tzw. globalnego dżihadu, co uzyskało swe potwierdzenie w rozwoju sieci komórek terrorystycznych oraz w szeregu zamachach przez należących do nich dżihadystów (Hiszpania, Wielka Brytania). Trzeci zaś etap rozpoczął się po roku 2005 r. i trwa do chwili obecnej. W każdym z trzech etapów za działalność radykalną odpowiada inne pokolenie dżihadystów. W pierwszym z powyższych było to przede wszystkim pokolenie weteranów wojny afgańskiej. W pokolenie dżihadystów wyrosłe w Europie, ale posiadające bliskie kontakty ze strukturami

${ }^{2}$ W jednym z raportów Europolu (TE-SAT 2008 - EU Terrorism Situation and Trend Report (2008), Europol, the Hague) podkreślono, że pojawienie się nowego pokolenia dżihadystów jest skutkiem zastosowania nowych technik propagandowo-rekrutacyjnych. 
ruchu w Azji (biorące np. udział w szkoleniach terrorystycznych na pograniczu afgańsko-pakistańskim). Trzecie zaś, dołączające dopiero do dżihadu, składa się z przedstawicieli diaspory muzułmańskiej urodzonych już w Europie lub nawet z Europejczyków, którzy z różnych powodów (w szczególności religijnej natury) dołączyli do ruchu.

\section{WZROST ZAGROŻENIA DŻIHADYSTYCZNEGO W EUROPIE?}

Zjawisko współczesnego terroryzmu islamskiego ściśle łączy się z istnieniem tzw. struktury sieciowej. Struktura ta składa się zarówno z komórek powiązanych ze sobą luźnymi relacjami, jak też i z całkowicie autonomicznych. Ich wielkość, typ oraz zakres aktywności związany jest po pierwsze z wyznaczonymi przez członków celami oraz zakresem środków, którymi oni dysponują. Po drugie zaś ważną zmienną mającą wpływ na funkcjonowanie komórek jest poziom zewnętrznego zagrożenia. W tym ostatnim przypadku sprawdza się zasada, że im mniejsza grupa osób współpracuje ze soba, tym mniejsze istnieje ryzyko infiltracji i rozbicia danej komórki. Szczególny sposób zorganizowania ruchu dżihadystów wpływa także na sposób obiegu informacji. Do poszczególnych komórek docierają ewentualnie informacje odnośnie konkretnych akcji, które mają zostać przez nie podjęte. Istnieje także możliwość sporadycznych kontaktów z centralą ruchu i poinformowanie jej o przedsiębranych akcjach, bądź zamiarach ich przeprowadzenia (i ustalenia w związku z tym szerszej strategii - w szczególności na płaszczyźnie regionalnej). Nie są kolportowane, z oczywistych powodów, informacje odnośnie składu poszczególnych komórek. Z rzadka dochodzi także do kontaktów między nimi (co oznacza konieczność przynajmniej wstępnego ustalenia zasięgu terytorialnego ich aktywności). W przypadku ruchu istnieje kilka przykładów (np. sieci komórek w Iraku czy Maghrebie) tworzenia struktur zarządzających, wzmacniających efektywność działań, ale zwiększających ryzyko wykrycia ich aktywności. W zależności od przypisanych poszczególnym komórkom zadań można wskazać na co najmniej ich trzy podstawowe typy:

- zarządzające - odpowiedzialne za wyznaczanie kierunku aktywności w odniesieniu do sieci komórek na danym terytorium, a także za działalność propagandową, akumulowanie funduszy na działalność operacyjną itp., w ich wewnętrznej strukturze daje się zauważyć hierarchizację poszczególnych funkcji;

- operacyjne - ich liczebność jest najmniejsza (zazwyczaj wchodzi w ich skład od 2 do 8 osób), posiadają one zdecentralizowany charakter, są zazwyczaj samowystarczalne i niezależne, choć funkcjonują w odniesieniu do wcześniej ustalonego kanonu zasad o charakterze operacyjno-ideologicznym, w przypadku ruchu istnieje możliwość kontaktowania się z ich członkami w szczególności za pośrednictwem specjalnych wysłanników centrali (agentów) znających ich osobiście;

- wspomagające - ich członkowie odpowiedzialni są przede wszystkim za proces rekrutacji (typują i sprawdzają kandydatów na członków ruchu).

Szacunki dotyczące liczby działających aktualnie w Europie komórek ruchu są rozbieżne. Dostępne dane wskazują że istnieje ich od trzydziestu kilku do prawie stu i rozsiane są po całym świecie. Wiele z nich udało się wykryć, dzięki podejmowanym przez 
odpowiednie służby państw zachodnich działaniom antyterrorystycznym. Do najważniejszych regionów objętych aktywnością sieci owych komórek zaliczyć można: Europę Zachodnią, Stany Zjednoczone, Półwysep Arabski, Afrykę Północną i Azję Południowo-Wschodnią.

W ostatnich kilkunastu latach znaczącej ewolucji uległ także proces rekrutacji nowych członków grup dżihadystycznych. W coraz większym stopniu wykorzystywane są obecnie narzędzia elektroniczne, co w istocie wpisuje tego rodzaju aktywność w tzw. dżihad elektroniczny czy też e-dżihad (Bunt, 2003: 26). Wśród wielu różnych metod rekrutacyjnych na uwagę zasługuje metoda sieciowa, realizowana wedle modelu przedstawionego poniżej.

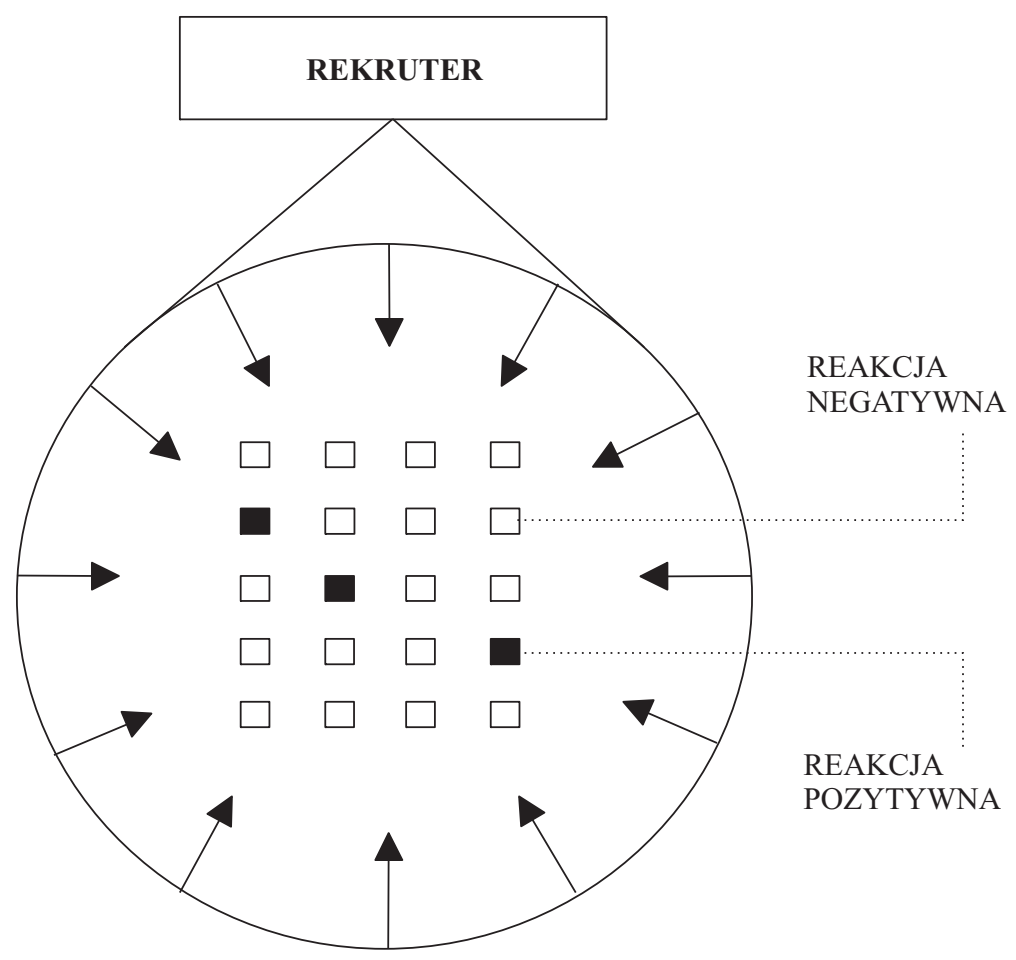

Rys. 1. Sieciowy model rekrutacji dżihadystycznej

Źródło: S. Gerwehr, S. Daly, Al-Qaida: Terrorist Selection and Recruitment, w: The McGraw-Hill Homeland Security Handbook, (eds.) D. Kamien, McGraw-Hill, New York 2006, s. 76.

$\mathrm{W}$ ramach powyższego modelu na uwagę zasługują dwa popularne w Europie kanały komunikacji pomiędzy rekruterem a rekrutowanym: Internet (w tym zwłaszcza strony społecznościowe radykalnych środowisk muzułmańskich) oraz meczety (z radykalnymi imamami jako rekruterami). W pierwszym przypadku na stronach internetowych umieszczane są różnego rodzaju materiały (wideo, zdjęcia, dokumenty $\mathrm{w}$ formie elektronicznej) promujące działalność dżihadystyczną oraz wskazujące na powody jej wsparcia. W drugim przypadku wezwanie do takich działań werbalizowane 
jest przez imama (Gerwer, Daly, 2006: 76). Badania przeprowadzone przez Petera R. Neumana wskazują na relatywnie wysoką skuteczność takiego typu rekrutacji. Powyższy autor znaczącą rolę przypisuje trzech rodzajom uczestników tego procesu: organizacjom społeczno-religijnym, imamom i aktywistom (Neumann, 2008: 32-33). Recepcja zaangażowania pierwszej grupy uczestników w powyższą działalność może nastręczać trudności przede wszystkim z uwagi na fakt, iż członkowie takich organizacji werbalizują zazwyczaj działalność opartą na wyrzeczeniu się przemocy, a skupiają się na indoktrynacji. Wśród najbardziej znanych przykładów tego typu grup wymienić można np. al-Muhadżiroun na czele z Omarem Bahri Mohammedem, która odłączyła się od grupy Hizb-ut Tahrir w 1996 r. Grupa ta działała w Wielkiej Brytanii, Danii i Pakistanie, a oprócz rekrutacji dżihadystów jej członkowie zajmowali się także gromadzeniem środków finansowych na walkę z niewiernymi (Neumann, 2008: 34). Markowi Hubandowi udało się niezmiernie dokładnie odtworzyć przyczyny, przebieg i skutki procesu radykalizacji i rekrutacji dżihadystycznej w Wielkiej Brytanii, wskazując w swoim modelu na kilkadziesiąt istotnych warunków, które należało spełnić, aby proces ten przebiegał efektywnie. Wśród nich wymienił m.in. podatność na indoktrynację ze strony przywódców duchowych (Huband, 2010: 124). Negatywnym efektem i potwierdzeniem skuteczności tego typu działań były m.in. zamachy w Londynie w lipcu 2005 r.

Przed 11 września 2001 r. częściowo zneutralizowano komórki ruchu we Włoszech, Niemczech, Wielkiej Brytanii, Kanadzie, Stanach Zjednoczonych, Republice Południowej Afryki, Tanzanii, Kenii, Jemenie, Albanii, Singapurze, Malezji, Jordanii, Algierii, Libii, Pakistanie i na Filipinach. Po 11 września nie nastąpił jednak proces atrofii strukturalnej ruchu dżihadystycznego. Proces rekrutacyjny ewoluuje w dynamiczny sposób kształtuje ową strukturę. Socjolgiczno-psychologiczne profile dżihadystów należących do tzw. trzeciego pokolenia nie pozwalają na jednoznaczną deskrypcję czynników przyczyniających się do relatywnego wzrostu liczby osób dołączających do grup dżihadystycznych. Peter Nesser oprócz czynnika religijno-politycznego wskazał m.in. na panujący zwłaszcza w Europie Zachodniej rasizm oraz tzw. „kognitywną otwartość" na idee nie kojarzone z sekularyzowanym Zachodem (Nesser, 2010: 91).

W analizach dotyczących ewolucji zagrożenia dżihadystycznego dość rzadko pojawiają się wnioski dotyczące zależności pomiędzy procesem radykalizacji a wzrostem powyższego zagrożenia. Poprzez radykalizację rozumieć należy proces poszukiwania nieortodoksyjnych sposobów wpływu na struktury społeczne, włącznie z użyciem siły w celu zmiany istniejącego porządku, w tym zniszczenia demokratycznych struktur i instytucji (Korteweg, Gohel, Heisbourg, Ranstorp, de Wijk, 2010: 31). Duńscy badacze zwrócili uwagę na dwa wymiary tego procesu: wewnętrzny i zewnętrzny. W tym pierwszym przypadku do radykalizacji przyczynia się m.in. brak debaty dotyczącej kwestii fundamentalnych (np. interpretacji zapisów pism religijnych) dla społeczności muzułmańskiej; stygmatyzacja i polityczna polaryzacja muzułmańskich społeczności w Europie; brak lub ograniczona asymilacja muzułmańskich imigrantów; aktywność imamów wspieranych organizacyjnie i finansowanych przez radykalne grupy (np. wahabbicke); bezkrytyczna akceptacja haseł radykalnych przez wielu młodych muzułmanów; łatwy dostęp do radykalnej literatury i materiałów propagandowych, gloryfikujących przemoc i wreszcie socjalizację do przemocy w więzieniach i grupach 
młodzieżowych. W drugim przypadku na proces radykalizacji w Europie wpływ mają tak ważne wydarzenia jak: konflikt w Czeczenii i Palestynie, w których prześladowana jest społeczność muzułmańska; zachodnie interwencje w państwach muzułmańskich, w związku z którymi cierpi ludność miejscowa, czy wspieranie przez Zachód (państwa europejskie) świeckich reżimów w świecie islamu, które powszechnie uważane są za autorytarne i skorumpowane (ibidem: 31-33). Czynniki te mają ciagle przemożny wpływ na wzrost radykalnych, antyzachodnich postaw wśród muzułmanów w wielu państwach europejskich.

\section{NAJWAŻNIEJSZE REGIONY AKTYWNOŚCI DŻIHADYSTYCZNEJ W EUROPIE}

Stopień zagrożenia ze strony komórek dżihadystycznych był $\mathrm{i}$ jest w państwach zachodnioeuropejskich różny. Ściśle był on skorelowany z wielkością diaspory muzułmańskiej i stopniem radykalizacji jej przedstawicieli. W latach dziewięćdziesiątych i na początku lat dwutysięcznych powyższe komórki powstawały w takich państwach jak Hiszpania, Francja, Belgia, Wielka Brytania, Holandia, Włochy, Niemcy, a także na południu Europy - w szczególności w Bośni-Hercegowinie. Aktualnie dostępne dane nie pozwalają na wskazanie konkretnej liczby istniejących komórek. Można jednakże założyć, że jest ich co najmniej kilkadziesiąt.

Jednym z najważniejszych przyczółków ruchu dżihadystycznego w Europie była i jest bez wątpienia Wielka Brytania. Dżihadyści pochodzący, albo działający na obszarze tego państwa odpowiedzialni byli za szereg istotnych zamachów terrorystycznych w latach dziewięćdziesiątych ubiegłego wieku oraz w latach dwutysięcznych (np. zamach na World Trade Center w Nowym Jorku z 1993 r. oraz w Londynie z 2005 r.). Nie bez powodu ukuto też termin „Londonistan” dający świadectwo powyższej tendencji. Dominantą wyróżniającą przykład brytyjski wydaje się być fakt, iż działało tam wielu islamistów uznanych za znaczących ideologów ruchu dżihadystycznego - na czele z Abu Katadą oraz Abu Musabem al-Surim. Ważną cezurą dotyczącą powyższego przykładu jest rok 2005. Od tego momentu zdecydowane działania władz brytyjskich (zwłaszcza MI5) wpłynęły pozytywnie na redukcję poziomu zagrożenia terrorystycznego w tym państwie. Zdaniem Jamesa Brandona wpłynęły na to także dwa inne czynniki: wolniejszy rozwój struktur organizacyjnych połączony z mniejszą liczbą młodych osób chcących wejść na ścieżkę dżihadu oraz mniejsza akceptacja haseł islamistycznych wśród muzułmańskiej diaspory w Wielkiej Brytanii (Brandon, 2011: 15). Trudno jednakże zgodzić się z ostateczną konkluzją, iż oznacza to trwałą redukcję zagrożenia terroryzmem islamskim. Nadal, bowiem obserwować można wzrost aktywności propagandowej dżihadystów w świecie wirtualnym, która nie pozostaje bez echa w świecie realnym. Wiele znanych już grup islamistycznych działających w Wielkiej Brytanii (np. Hizb al-Tahrir czy al-Muhadżiroun) traci, co prawda, na znaczeniu. Ich miejsca nie zajmująjednak zorganizowane i zhierarchizowane struktury, a pojedyncze autonomiczne komórki operacyjne lub też nawet terroryści indywidualni, którzy stanowić mogą poważne wyzwanie dla bezpieczeństwa wewnętrznego tego państwa. 
Dostępne dane dotyczące wzrostu zagrożenia terroryzmem islamskim w Niemczech pozwalają na stwierdzenie, iż przesadzone i nieuprawnione wydają się opinie wskazujące na to państwo, jako główne, obok Wielkiej Brytanii, zaplecze ruchu dżihadystycznego w Europie. $Z$ drugiej jednak strony nie wolno trywializować zagrożenia pochodzącego z Niemiec, które przejawia się choćby w aktywności pochodzących z tego kraju muzułmanów m.in. Islamskiej Unii Dżihadu (Steinberg, 2013: 77-102), z którą w istocie współpracował Fritz Golewicz - Niemiec, polskiego pochodzenia czy tureckim Hezbollahu (ibidem: 111-124), ściśle powiązanym z radykalnymi przedstawicielami tureckiej diaspory w Niemczech.

Władze niemieckie oficjalnie badają skalę zagrożenia dżihadystycznego od połowy dekady lat dwutysięcznych. Maksymalna liczba osób podejrzewanych lub oskarżonych o aktywność terrorystyczną oscylowała wokół liczby 130 (Gohel, 2011: 12), co wydaje się być liczbą znacząco zaniżoną. Niemcy były traktowane przez dżihadystów jako tzw. państwo tranzytowe lub zaplecze do przygotowywania zamachów w innych częściach Europy czy świata. Wśród istotnych przykładów takiej aktywności wymienić można choćby zamachy z 11 września $2001 \mathrm{r}$. Nie bez powodu ukuto zatem termin „Kufaristan”. Dzięki współpracy międzynarodowej (także w dziedzinie wywiadu) oraz aktywności służb niemieckich udało się wyeliminować część sieciowej struktury ruchu dżihadystycznego w tym państwie. Należy jednak podejrzewać, że nadal istnieją tam komórki, które mają operacyjne możliwości przeprowadzenia ataku terrorystycznego, także w państwach ościennych. Tego typu zagrożenia władze polskie nie powinny ignorować.

Ostatni etap ewolucji ruchu dżihadystycznego w Europie związany jest z dwoma istotnymi zmiennymi, ściśle związanymi z przemianami strukturalnymi i wpływem czynnika osobowościowego na rozwój ruchu. Chodzi w tym przypadku o zwrócenie uwagi na rolę tzw. emisariuszy (a więc agentów ruchu), którzy odbudowują struktury operacyjne na Zachodzie. Druga zmienna wiąże się zaś z popularyzacją narracji, zwłaszcza w świecie wirtualnym, promującej postawy heroiczne, co może wpływać na radykalizację postaw jednostek (a więc i wzrost popularności terroryzmu indywidualnego). Zgodnie z wnioskami wypływającymi z analizy 16 przypadków przygotowywanych przez dżihadystów zamachów terrorystycznych, przeprowadzonej przez Mitchella D. Silbera tendencje te widoczne są w odniesieniu do wielu państw europejskich, m.in. Wielkiej Brytanii, Holandii, Hiszpanii i Niemiec (Silber, 2011: 2). Proces ten nazwać można procesem jednostkowej autoradykalizacji inspirowanej ideologią dżihadystyczną.

Analiza dotychczasowych przykładów aktywności dżihadystycznej w Europie wskazuje na coraz mniejszą, ale nie marginalną popularność egalitarnych idei, łączących aktywność dżihadystyczą z aktywnością angażującą małe grupy społeczne. W literaturze dżihadystycznej ciagle popularne są idee współpracy w ramach grupy ( $\left.d \dot{z} a m a{ }^{\prime} a\right)$, organizacji (tanzim) czy ruchu (haraka). Dotychczasowe akcje terrorystyczne podejmowane przez islamistów inspirowane były z zewnątrz i wymagały długotrwałych (najczęściej wieloletnich) przygotowań (Nesser, 2008: 3). Jednakże począwszy od 2001 r., a więc od przypadku Richarda Reida (tzw. shoebomber), próbującego przeprowadzić zamach terrorystyczny w samolocie linii American Airlines lecącym z Rzymu do Miami, poprzez przypadek próby przeprowadzenia zamachu w październiku 2009 r. przez Umara 
Farouka Abdulmuttallaba (tzw. underwearbomber), a skończywszy na co najmniej sześciu przypadkach prób lub udanych zamachów przeprowadzonych przez jednostki na obszarze Europy w latach 2010-2011 (Nesser, 2012: 16), da się zauważyć coraz większą popularność działań indywidualnych. Niezmiernie ważnym był także przypadek Mohammeda Meraha, odpowiedzialnego za atak terrorystyczny w Tuluzie w marcu 2012 r. Większość z powyższych przypadków inspirowana była jednak, z zewnątrz. Ich rosnąca liczba odzwierciedla jednak pewną tendencję. Podobne tendencje zauważyć można także w innych państwach europejskich, np. we Włoszech (Vidino, 2013: 17-20).

Najistotniejszym zagrożeniem związanym z ewolucją ruchu dżihadystycznego jest jednak aktywność terrorystów indywidualnych. Nie partycypują oni w aktywności żadnych struktur, zaś proces ich radykalizacji ma wymiar autonomiczny. Trudno przewidzieć zarówno moment ich terrorystycznej aktywizacji, jak też wybór konkretnego celu ataku. Jeśli zauważy się jednak fakt rosnącej fali radykalizacji aktywności dżihadystów, to nie można wykluczyć, że w obliczu coraz większych sukcesów działań antyi kontrterrorystycznych w Europie Zachodniej przynajmniej część z nich zdecyduje się na przeprowadzenie ataków terrorystycznych w innych regionach Europy (np. w Europie Środkowej). Bodźcem do takiej aktywności mogą być ważne wydarzenia sportowe czy społeczne, absorbujące uwagę nie tylko lokalnej społeczności.

$* * *$

Globalny ruch dżihadystyczny cały czas rozbudowuje swoje wpływy w Europie Zachodniej i Południowej. Ważnym przyczółkiem ruchu w latach dziewięćdziesiątych, a więc w pierwszym okresie funkcjonowania, był obszar byłej Jugosławii, w tym w szczególności Bośnia-Hercegowina i Kosowo. W międzyczasie rozbudowywano jego strukturę także w państwach zachodnich.

Mylne jest przeświadczenie, iż znaczące sukcesy w walce $\mathrm{z}$ dżihadystami, np. eliminacja znanych ideologów czy przywódców ruchu dżihadystycznego (np. Osamy bin Ladena czy Anwara al-Awlakiego) oznacza trwałą redukcję zagrożenia dżihadystycznego. Obserwowana od dwóch dekad ewolucja ruchu dżihadystycznego jednoznacznie dowodzi, iż żadne działania kontrterrorystyczne nie są w stanie zapobiec dalszemu rozwojowi jego struktur. Najlogiczniejszą konstatacją w związku z powyższą obserwacją będzie stwierdzenie, iż kolejne ataki terrorystów islamskich są prawdopodobne.

Niezwykle trudno jest nakreślić ostateczną mapę zagrożeń ze strony dżihadystów na kontynencie europejskim. Wskazane w artykule zmienne mające wpływ na ewolucję ruchu dżihadystycznego dynamicznie wpływają na proliferację tego zagrożenia na całym kontynencie europejskim. Na przestrzeni ostatnich dwóch dekad komórki dżihadystyczne założone zostały w takich państwach jak: Belgia, Holandia, Dania, Wielka Brytania, Hiszpania, Niemcy, Włochy. Aktywnością dżihadystyczną objęty był ponadto obszar Bałkanów, w tym zwłaszcza Bośnia-Hercegowina, na terenie której osiedliło się wielu uczestników europejskiego dżihadu.

Zasięg aktywności dżihadystów jest dziś nieograniczony. Coraz większą popularność zdobywa ponadto idea zamachów samobójczych podejmowanych przez jednostki. Zdaniem wielu taktyków ruchu dżihadystycznego jest to jedno z najefektywniejszych 
narzędzi walki zbrojnej, które coraz częściej stosowane będzie w państwach Zachodu. Presja wywierana na islamistach w Europie poprzez działania anty-i kontrterrorystyczne będzie wręcz zmuszała ich do zwrócenia się w stronę tego typu aktywności na o wiele większą skalę niż dotychczas. W związku z tym żadne państwo europejskie, nie może tej nowej sytuacji ignorować. Jednym z ważniejszych instrumentów wykorzystywanych w tym zakresie jest polityka przeciwdziałania radykalizacji islamistycznej, szczególnie efektywnie rozwijana w takich państwach, jak: Wielka Brytania, Holandia czy Dania (Brandon, Vidino, 2012: 16-18).

\section{Bibliografia}

Atwan A. B. (2008), The Secret History of al Qaeda, Berkeley-Los Angeles

Brachman J. M. (2009), Global Jihadism. Theory and practice, London-New York.

Brandon J. (2011), The Decline of Jihadist Activity in the United Kingdom, „CTC Sentinel” October, Vol. 4, Issue 10.

Brandon J., Vidino L. (2012), European Experiences in Counterradicalization, „CTC Sentinel”, Vol. 5, Issue 6.

Bunt G. R. (2003), Islam in the Digital Age. E-Jihad, Online Fatwas and Cyber Islamic Environments, Pluto Press, London-Sterling.

Egarton F. (2011), Jihad in the West. The Rise of Militant Salafism, Cambridge.

Gerwehr S., Daly S. (2006) Al-Qaida: Terrorist Selection and Recruitment, w: The McGraw-Hill Homeland Security Handbook, (ed.) D. Kamien, McGraw-Hill, New York.

Global Salafism. Islam's New Religious Movement (2009), (ed.) R. Meijer, New York.

Gohel S. M. (2011), Germany Increasingly a Center for Terrorism in Europe, „CTC Sentinel”, Vol. 4, Issue 8.

Gunaratna R. (2003), Inside al Qaeda. Global Network of Terror, Berkley Books, New York.

Huband M. (2010), Radicalization and recruitment in Europe, w: Understanding Violent Radicalization. Terrorist and Jihadist Movements in Europe, (ed.) M. Ranstorp, Abingdon.

Khosrokhavar F. (2009), Inside Jihadism. Understanding Jihadi Movements Worldwide, Boulder-London.

Korteweg R., Gohel S., Heisbourg F., Ranstorp M., de Wijk R. (2010), Background contributing factors to terrorism. Radicalization and recruitment, w: Understanding Violent Radicalization. Terrorist and Jihadist Movements in Europe, (ed.) M. Ranstorp, Abingdon.

Nesser P. (2008), How did Europe's Global Jihadis Obtain Training for their Militant Causes?, „Terrorism and Political Violence", Vol. 20, Issue 2.

Nesser P. (2010), Joining jihadi terrorist cells in Europe, w: Understanding Violent Radicalization. Terrorist and Jihadist Movements in Europe, (ed.) M. Ranstorp, Abingdon.

Nesser P. (2012), Individual Jihadist Operations in Europe: Patterns and Challenges, „CTC Sentinel” Vol. 5, Issue 1.

Neumann P. R. (2008), Joining Al-Qaeda. Jihadist Recruitment in Europe, Adelphi Paper 399, London-New York.

Pargeter A. (2008), The New Frontiers of Jihad. Radical Islam in Europe, University of Pensylvania Press, Philadelphia.

Renard T. (2008), Europol Reveals Trends in Jihadi Terrorism in Europe, „Terrorism Monitor”, Vol. VI, Issue 9. 
Roy O. (2004), Globalized Islam. The Search for a New Ummah, New York 2004.

Sageman M. (2004), Understanding Terror Networks, Philadeplhia.

Al-Shishani, M. B. (2011), Understanding Strategic Change in al-Qaeda's Central Leadership after bin Laden, „Terrorism Monitor”, Vol. IX, Issue 23.

Silber M. D. (2011), Al-Q'aida's Center of Gravity in a Post-Bin Ladin World, „CTC Sentinel”, Vol. 4, Issue 11-12.

Vidino L. (2007), Current Trends in Jihadi Networks in Europe, „Terrorism Monitor”, Vol. V, Issue 20.

Vidino L. (2013), The Evolution of Jihadism in Italy: Rise in Homegrown Radicals, „CTC Sentinel”, Vol. 6, Issue 11-12.

Wejkszner A. (2010), Ewolucja terroryzmu motywowanego ideologia religijna na przyktadzie salafickiego ruchu globalnego dżihadu, Poznań.

Wejkszner A. (2012), The Era of Network Terrorism. The Evolution of the Organisational Structure of the Global Salafi Jihad Movement at the Beginning of the Twenty-First Century, „Przegląd Strategiczny", Vol. II, nr 2.

Wojciechowski S. (2013a), The Hybridity of Terrorism. Understanding Contemporary Terrorism, Berlin.

Wojciechowski S. (2013b), Terroryzm na poczatku XXI wieku. Pojęcie. Przejawy. Przyczyny, Poznań.

\title{
STRESZCZENIE
}

W niniejszej publikacji skupiono się na przedstawieniu źródeł i najważniejszych przejawów radykalizmu islamskiego w Europie. Zwrócono w szczególności uwagę na historyczne i ideologiczne determinanty rozwoju tego zjawiska. Wskazano najważniejsze etapy ewolucji zagrożenia dżihadystycznego oraz aktorów mających wpływ na jego ewolucję. Uwzględniając powyższe przesłanki w artykule zawarto ponadto najważniejsze wnioski dotyczące wzrastającego poziomu powyższego zagrożenia dla wybranych państw europejskich, w okresie ostatnich kilkunastu lat wraz ze wskazaniem zmiennych wpływających na ów poziom w postaci: procesu radykalizacji społeczności muzułmańskich w Europie, zmian w taktyce i organizacji grup dżihadystycznych, sukcesu akcji rekrutacyjnych i antyterrorystycznej aktywności państw Zachodu.

\section{THE EVOLUTION OF THE JIHADIST THREAT IN EUROPE}

\begin{abstract}
The purpose of this article is to analyze the most important sources and manifestations of Islamic radicalism in Europe. In order to achieve this aim the historical and the ideological determinants of the development of this phenomenon have been presented, followed by identification of the main stages of the evolution of jihadist threats and actors affecting its evolution. In that respect main argument of this article is that the jihadist threat to the security of selected European countries has relatively increased in the last few years and is dependent of the following issues: the process of radicalization of Muslim communities in Europe, changes in tactics and organization of jihadi groups, the success of the recruitment process and anti-terrorist activity of Western countries.
\end{abstract}

